\title{
ANALISIS METODE RBF-NN DENGAN OPTIMASI ALGORITMA GENETIKA PADA PERAMALAN MATA UANG EUR/USD
}

\author{
Nengah Widiangga ${ }^{1}$, Agus Dharma ${ }^{2}$, Made Sudarma $^{3}$
}

\begin{abstract}
This paper discuss about EUR/USD forex forecasting using RBF-NN (Radial Basis Function - Neural Network) method without optimization and RBF-NN optimized by 3models of Genetic Algorithm (GA) and Adaptive Genetic Algorithm (AGA). Forecasting, which is done with the help of MATLAB program, uses 2 types of data (daily high and daily low) and 2 to 5 clusters model. The accuracy is shown as MAPE (Mean Absolute Percentage Error) value. In daily low data, method with the best MAPE is GA type II (3 clusters) with MAPE value of $0.2286 \%$, while in daily high data, method with the best MAPE is AGA type II (3 clusters) with MAPE value of $0.2190 \%$. GA type II and AGA type II has certain technique which searches around RBF-NN's weight, and this technique proofed to be effective in EUR/USD case. Improvement in accuracy that GA type II and AGA type II gives to RBF-NN method may also be used in other currency as well.
\end{abstract}

Intisari-Penelitian ini membahas tentang peramalan EUR/USD menggunakan metode RBF-NN (Radial Basis Function - Neural Network) tanpa optimasi dan RBF-NN yang dioptimasi dengan 3 model AG/AGA (Algoritma Genetika dan Algoritma Genetika Adaptif). Sistem RBF-NN dapat diterapkan pada data dengan karakteristik nonlinear dan fluktuatif seperti data EUR/USD. Permasalahan akurasi muncul jika terjadi solusi lokal dalam sistem RBF-NN dan metode AG/AGA dapat digunakan untuk mengatasi solusi lokal tersebut. Keakuratan dari peramalan ditunjukkan lewat nilai MAPE (Mean Absolute Percentage Error). Pada data daily low, metode terbaik adalah Algoritma Genetika II dengan MAPE sebesar 0,2286\%, sementara pada data daily high metode terbaik adalah Algoritma Genetika Adaptif II dengan MAPE sebesar 0,2190\%. Metode AG II dan AGA II didukung teknik pencarian di dekat bobot RBFNN yang terbukti efektif pada kasus mata uang EUR/USD. Perbaikan akurasi yang diberikan AG II dan AGA II terhadap metode RBF-NN dapat diterapkan pada peramalan mata uang lainnya.

Kata Kunci- EUR/USD, RBF-NN, algoritma genetika, algoritma genetika adaptif, cluster, MAPE, daily high, daily low.

\section{Pendahuluan}

Pasar mata uang atau sering juga disebut Forex adalah pasar yang terus beraktivitas selama 24 jam per hari, 7 hari per minggu. Salah satu komoditas yang diperjualbelikan di Forex

${ }^{1}$ Mahasiswa Pascasarjana, S2 Teknik Elektro Universitas Udayana, Jln. PB. Sudirman Denpasar Bali 80232 INDONESIA (telp: 0361-239599; e-mail: widiangga@gmail.com)

${ }^{2,3}$ Dosen Pascasarjana, S2 Teknik Elektro Universitas Udayana, Jln. PB. Sudirman Denpasar Bali 80232 INDONESIA (telp: 0361-239599; e-mail: agus_dharma@unud..ac.id, msudarma@unud.ac.id)

Nengah Widiangga: Analisis Metode RBF-NN dengan... adalah mata uang Euro (EUR) dan US Dollar (USD).

Kurs atau nilai perbandingan dari kedua mata uang ini disebut dengan EUR/USD sementara orang yang bertransaksi di Forex dengan tujuan mendapatkan keuntungan disebut Trader. Data Forex terdiri dari empat bagian yaitu nilai Open, Close, Maximum dan Minimum untuk setiap time frame yang berbeda (harian, mingguan, 1 jam, 4 jam).

Karakteristik data Forex mirip dengan karakteristik data financial time series yang bersifat nonlinear dan fluktuatif. Karena pola yang cenderung rumit, maka sulit untuk melakukan perhitungan manual dengan alat hitung biasa dan melakukan peramalan dengan mengenali pergerakan pola tersebut [1]. Peramalan data Forex adalah proses untuk memperkirakan nilai kurs mata uang tersebut di masa depan. Trader memerlukan nilai peramalan untuk menentukan tindakan apa yang akan diambil; membeli, menjual atau menunggu.

Penulis memilih EUR/USD karena mata uang ini didukung oleh dua kekuatan ekonomi terbesar dunia yaitu Amerika Serikat dan Uni Eropa [2]. Sebagai akibatnya EUR/USD bersifat likuid dan berpotensi menghasilkan keuntungan finansial apabila peramalannya memberikan hasil yang akurat.

Berdasarkan jurnal-jurnal yang telah diterbitkan, beberapa peneliti telah mencoba meramalkan data Forex dengan metode Statistik, Fuzzy Logic, Neural Network [3], [4]. Salah satu permasalahan yang ditemui pada peramalan data Forex adalah akurasi yang kurang baik karena data yang bersifat nonlinear dan fluktuatif.

Salah satu model dari Jaringan Syaraf Tiruan (JST) yang dapat digunakan dalam peramalan adalah RBF-NN (Radial Basis Function - Neural Network). Jaringan ini menggunakan model yang mentransformasi input menggunakan fungsi Gaussian dan dilanjutkan secara linear pada output [5]. Fungsi Gaussian bersifat nonlinear sehingga dapat diterapkan untuk data yang memiliki karakteristik nonlinear seperti data Forex. Sistem RBF-NN yang menggunakan LMS (Least Mean Square) memiliki keterbatasan akurasi jika dalam pencarian yang terjadi adalah solusi lokal.

Algoritma Genetika (AG) dan Algoritma Genetika Adaptif (AGA) dapat digunakan untuk mengatasi solusi lokal tersebut. AG dan AGA bekerja dengan mencari bobot terbaik pada model RBF-NN [6]. Dalam praktiknya, AG dan AGA memiliki banyak pilihan model tergantung dari jenis seleksi, crossover (perkawinan) dan mutasi yang dipilih. Sistem AG dan AGA bergantung pada probabilitas, akibatnya solusi yang terbaik belum tentu bisa diperoleh. Pada penelitian sebelumnya [7], metode RBF-NN dioptimasi dengan 1 model AG dan AGA.

Pada penelitian ini, penulis menganalisis metode RBF-NN dengan optimasi AG dan AGA sebanyak 3 model untuk 
peramalan mata uang EUR/USD. Hasil analisis adalah nilai error dalam bentuk MAPE (Mean Absolute Percentage Error), semakin kecil MAPE maka metode tersebut semakin baik. Pada setiap cluster, mulai dari model dengan 2 hingga 5 cluster, ada 7 buah nilai MAPE yang akan dibandingkan yaitu nilai MAPE dari metode RBF-NN tanpa optimasi, 3 model RBF-NN dengan AG dan 3 model RBF-NN dengan AGA. Metode RBF-NN dengan optimasi AG dan AGA bertujuan memberikan hasil peramalan yang lebih baik daripada metode RBF-NN tanpa optimasi.

\section{KAJIAN PUSTAKA}

\section{A. KMEANS Cluster dan RBF-NN}

Data Clustering merupakan salah satu metode data mining yang bersifat tanpa arahan (unsupervised). K-Means berusaha membagi-bagi data yang ada ke dalam satu atau lebih cluster. Metode ini mempartisi data ke dalam cluster sehingga data yang memiliki karakteristik yang sama dikelompokkan ke dalam satu cluster sementara data dengan karakteristik yang berbeda dikelompokkan ke dalam cluster yang lain. Adapun tujuan dari data clustering ini adalah untuk meminimalkan objective function sehingga meminimalkan variasi di dalam suatu cluster dan memaksimalkan variasi antar cluster.

Algoritma $K$-Means dimulai dengan pemilihan nilai $\mathrm{K}$ secara acak, dengan nilai $\mathrm{K}$ menunjukkan jumlah cluster yang ingin dibentuk. Untuk sementara nilai tersebut menjadi pusat dari cluster (centroid). Selanjutnya perhitungan jarak dilakukan dengan rumus Euclidian untuk setiap data yang ada terhadap masing-masing centroid hingga didapatkan jarak terdekat. Setiap data lalu diklasifikasikan berdasarkan kedekatannya dengan centroid. Langkah-langkah tersebut dilakukan hingga nilai centroid tidak berubah (stabil).

RBF-NN $(\varphi)$ merupakan fungsi dengan keluaran yang simetris terhadap center $(c)$ tertentu atau dinyatakan sebagai $\varphi$ $=\varphi\|x-c\|$, dimana $\|$. $\|$ merupakan vektor normal. Fungsi yang digunakan misalnya Gaussian, Multiquadric, Inverse Quadratic, Inverse Multiquadric, dll. Jaringan RBF terdiri atas tiga layer yaitu layer input, hidden layer dan layer output. Struktur dasar jaringan RBF-NN ditunjukkan pada Gambar 1.

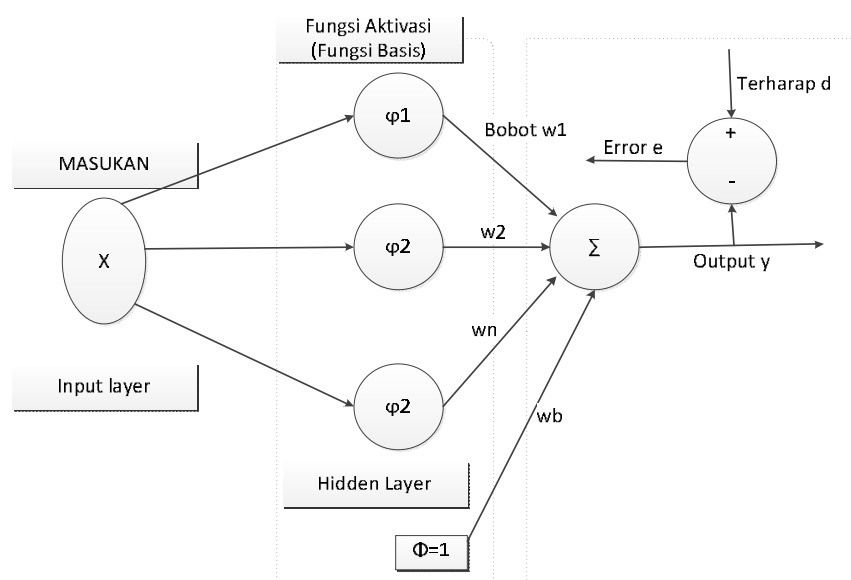

Gambar 1: Struktur RBF-NN [7]
Setelah menentukan pusat dan jumlah neuron, langkah selanjutnya adalah menentukan matriks $\varphi$ dan matrik $t$ [8]. Setelah matriks ini ditentukan, langkah selanjutnya adalah mencari bobot $(w)$. Elemen matrik $\varphi$ dibentuk dengan menggunakan model sebagai berikut: $\left[\exp \left(-\frac{\| \text { data-center } \|^{2}}{2 \sigma^{2}}\right)\right]$; data diambil dari data pengujian atau training dan center diambil dari pusat cluster. Nilai untuk $\sigma$ dapat diambil suatu konstanta yang menandakan jarak radial data tersebut dengan center.

Matrik $t$ mengambil elemen-elemen dari data pengujian dan training. Persamaan linearnya sesuai dengan (1).

$$
\varphi w=t
$$

Bobot ( $w$ ) dapat dicari dengan pendekatan least-square sesuai dengan (2).

$$
w=\left(\varphi^{T} \varphi\right)^{-1} \varphi^{T} t
$$

Pada penelitian ini, hidden layer dari RBF-NN dibentuk menggunakan center dari masing-masing cluster. Setiap data yang dimasukkan melalui input layer akan diolah dalam hidden layer, kemudian dikalikan dengan bobot sesuai (1). Hasil perkalian ini merupakan peramalan yang dihasilkan oleh RBF-NN.

\section{B. Algoritma Genetika, Algoritma Genetika Adaptif, MAPE}

Algoritma Genetika adalah teknik optimasi dan pencarian berdasarkan prinsip-prinsip genetika dan seleksi alam. Optimasi sendiri dapat diartikan sebagai mencari hasil terbaik dari segala hal yang kita lakukan [9]. Algoritma Genetika dan Algoritma Genetika Adaptif meliputi langkah-langkah yaitu : Representasi Kromosom dan Inisialisasi Kromosom, Evaluasi Fitness, Seleksi, Crossover (perkawinan), Mutasi, update probabilitas crossover dan probabilitas mutasi (khusus untuk AGA).

Meskipun tidak ada parameter baku untuk setiap kasus yang menggunakan algoritma genetika, penulis menggunakan ketentuan berikut.

a. Penggunaan azas elitisme.

b. Tingkat crossover ditentukan sebesar $70 \%$ (berdasarkan peluang crossover pada algoritma genetika adaptif).

c. Tingkat mutasi ditentukan sebesar $40 \%$ (berdasarkan peluang mutasi pada algoritma genetika adaptif).

d. Populasi ditentukan sebesar 100.

Tiga model AG yang digunakan dalam penelitian ini adalah sebagai berikut.

a. AG Tipe I : rank-based fitness assignment, single point crossover, single point mutation. Langkah pertama adalah menginisialisasi kromosom dengan bobot yang sesuai dengan cluster, lalu pencarian MAPE dan pemeringkatan (1-100). Crossover dilakukan berdasarkan prinsip single point dengan bantuan bilangan acak. Bilangan acak ini menentukan titik-titik mana yang akan mengalami crossover dan digunakan untuk penambahan tanda minus. Proses mutasi berlangsung dengan mengalikan nilai bobot dengan bilangan acak, 
selanjutnya dikalikan kembali dengan 100. Proses AG tipe I akan berakhir jika telah mencapai 50 epoch.

b. AG Tipe II : roulette wheel, single point crossover (random number), single point random mutation. Langkah pertama adalah menginisialisasi kromosom dengan bobot, lalu dilakukan pemeringkatan berdasarkan MAPE. Berikutnya crossover dilakukan dengan metode roulette wheel; dalam hal ini bobot yang peringkatnya lebih rendah akan digantikan oleh bobot yang peringkatnya lebih tinggi. Proses mutasi melibatkan seluruh kromosom, dimana bobot akan melalui proses pengalian dengan bilangan acak, bobot minimum dan bobot maksimum. Algoritma Genetika tipe 2 akan berakhir jika telah mencapai 50 epoch, setelah itu MAPE seluruh kromosom akan dihitung.

c. AG Tipe III : stochastic selection, single point crossover, mutation with random multiplication. Langkah pertama adalah menginisialisasi kromosom dengan bobot yang sesuai dengan cluster, lalu dilakukan pemeringkatan berdasarkan nilai MAPE. Tahap crossover dimulai dengan stochastic selection dan dilanjutkan dengan Single point crossover yang dilaksanakan 10 kali setiap epoch. Proses mutasi hanya melibatkan kromosom yang mengalami crossover melalui mekanisme pengalian bobot dengan bilangan acak dan perpangkatan acak dari -1 (mutation with random multiplication). Algoritma Genetika tipe 3 akan berakhir jika telah mencapai 50 epoch, setelah itu MAPE seluruh kromosom akan dihitung.

AGA pada dasarnya sama dengan AG namun perbedaan mendasar pada AGA adalah adanya penentuan probabilitas crossover dan probabilitas mutasi sesuai dengan nilai fitness.

Rumus yang digunakan untuk melakukan update probabilitas crossover dan probabilitas mutasi sesuai dengan (3) dan (4).

$$
\begin{aligned}
& p_{c}=k_{1}\left(f_{\text {max }}-f^{\prime}\right)\left(f_{\text {max }}-\hat{f}\right) \\
& p_{m}=k_{2}\left(f_{\text {max }}-f^{\prime}\right)\left(f_{\text {max }}-\hat{f}\right)
\end{aligned}
$$

dengan batasan

$$
k_{1}, k_{2}, k_{3} \leq 1.0
$$

Keterangan :

$p_{c}$ adalah probabilitas crossover

$p_{m}$ adalah probabilitas mutasi

$f_{\text {max }}$ adalah fitness maksimal

$f$ adalah fitness terbesar dari solusi yang dimutasi

$f^{\prime}$ adalah fitness terbesar dari solusi yang disilangkan

$\hat{f}$ adalah rata-rata fitness

Nilai $p_{m}=0,6, p_{c}=0,3, k_{1}=0,7$ dan $k_{2}=0,3$. Nilai-nilai ini ditetapkan dengan harapan memperbesar peluang untuk crossover dari kromosom-kromosom yang memiliki fitness baik, dan memperbesar peluang mutasi dari kromosomkromosom dengan fitness jelek [7].
Tiga model AGA yang digunakan dalam penelitian ini adalah sebagai berikut.

a. AGA Tipe I

Langkah pertama adalah menginisialisasi kromosom lalu pencarian MAPE dan pemeringkatan. Tahap crossover dilakukan berdasarkan probabilitas crossover pada kromosom 1-6 dan nilai Update. Crossover berlangsung jika bilangan acak lebih dari atau sama dengan 0,5 dan nilai Update lebih besar daripada probabilitas crossover. Proses mutasi berlangsung jika nilai update lebih besar daripada probabilitas mutasi. Algoritma Genetika Adaptif tipe 1 akan berakhir jika telah mencapai 50 epoch, setelah itu MAPE seluruh kromosom akan dihitung.

b. AGA Tipe II

Langkah pertama pada Algoritma Genetika Adaptif Tipe II adalah menginisialisasi kromosom lalu pencarian MAPE dan pemeringkatan. Kemudian crossover dilakukan dengan metode roulette wheel; dalam hal ini bobot yang peringkatnya lebih rendah akan digantikan oleh bobot yang peringkatnya lebih tinggi. Crossover berlangsung jika nilai Update lebih besar daripada probabilitas crossover. Penentuan crossover dengan roulette wheel dilaksanakan 10 kali setiap epoch. Proses mutasi ditentukan oleh nilai Update setiap kromosom. Algoritma Genetika Adaptif tipe 2 akan berakhir jika telah mencapai 50 epoch, setelah itu MAPE seluruh kromosom akan dihitung.

c. AGA Tipe III

Langkah pertama pada Algoritma Genetika Adaptif Tipe III adalah menginisialisasi kromosom lalu pencarian MAPE dan pemeringkatan. Selanjutnya dilakukan stochastic selection, dimana kromosom yang akan melakukan crossover ditentukan lewat bilangan acak. Crossover berlangsung jika nilai Update lebih besar daripada probabilitas crossover. Proses mutasi ditentukan oleh nilai Update setiap kromosom. Algoritma Genetika Adaptif tipe 3 akan berakhir jika telah mencapai 50 epoch, setelah itu MAPE seluruh kromosom akan dihitung.

\section{MAPE (Mean Absolut Percentage Error)}

MAPE sesuai dengan (5) digunakan untuk untuk menilai kinerja suatu proses dengan menyatakan perbedaan antara data ramalan $\left(F_{t}\right)$ dengan data aktual $\left(A_{t}\right)$ dalam bilangan riil melalui persentase dengan mengabaikan indikator positif atau negatif pada galat [10].

$$
M A P E=\left(\frac{100}{n}\right) \sum_{t=1}^{n}\left|\frac{A_{t}-F_{t}}{A_{t}}\right|
$$

dengan $n$ adalah banyaknya data.

\section{METODELOGI PENELITIAN}

\section{A. Tahapan Penelitian}

Tahapan pada penelitian ini mencakup 3 hal yaitu : 
1. Pre-processing yang meliputi proses pengambilan data dan membagi data tersebut menjadi data training dan data pengujian.

2. Processing yang meliputi pembentukan arsitektur jaringan RBF-NN dan optimasi bobot dengan AG dan AGA.

3. Post processing yang meliputi pengujian model RBFNN dan RBF-NN yang dioptimasi dengan AG/AGA.

\section{B. Pengambilan dan Pengolahan Data}

Pengambilan data training dan data pengujian meliputi langkah-langkah berikut.

a. Membuka terminal MT4 Liteforex.

b. Pilih tools, masuk ke History Centre kemudian memilih datanya (dalam hal ini Daily untuk kurs EUR/USD) dan klik Export. Format default-nya adalah dalam bentuk csv.

c. Data dalam format csv dibuka dengan MS Excel lalu di-edit untuk mengambil data daily high dan daily low.

d. Macro VBA digunakan untuk mengambil 1000 data training dan 300 data pengujian. Data ini akan disimpan ke dalam variabel MATLAB.

Data training menggunakan data tanggal 20 Oktober 2009 hingga 22 Agustus 2013, sementara data pengujian menggunakan data tanggal 23 Agustus 2013 hingga 17 Oktober 2014.

\section{Pembentukan Cluster dan Pemodelan RBF-NN}

Pembentukan cluster menggunakan 5 buah program. Masing-masing program mewakili jumlah cluster yang berbeda ( $2-5$ cluster $)$. Clustering dengan metode K-means cluster memanfaatkan fungsi bawaan dari MATLAB yaitu kmeans(). Nilai center yang dihasilkan fungsi kmeans() akan dimasukkan ke dalam fungsi basis RBF-NN.

Langkah-langkah pembentukan Matrik $\varphi$ dan $t$ adalah sebagai berikut:

a. Matrik $\varphi$ memiliki jumlah kolom sesuai dengan jumlah cluster dan barisnya merupakan data training urutan pertama hingga 999. Kolom pertama dibentuk berdasarkan pusat cluster pertama, kolom kedua berdasarkan pusat cluster kedua, dst. Jika data pertama adalah 1,2837 dan data kedua adalah 1,2845, maka pusat cluster pertama adalah 1,2500 dan pusat cluster kedua adalah 1,2600, maka matrik $\varphi$ yang dibentuk dari 2 data awal ini adalah :

b.

$\left[\exp \left(-\frac{\|1.2837-1.2500\|^{2}}{2 \sigma^{2}}\right) \exp \left(-\frac{\|1.2845-1.2600\|^{2}}{2 \sigma^{2}}\right)\right]$

dengan $\sigma$ diambil sama dengan 1, yang merupakan pendekatan fungsi Gaussian dengan radial sebesar 1 terhadap data Forex.

c. Matrik $t$ terdiri dari data training urutan kedua hingga urutan seribu. Matrik $t$ adalah sasaran yang akan dicapai dengan menyesuaikan nilai bobot. Matrik t yang terbentuk dari poin a di atas adalah : [1,2845]. Jadi untuk 2 cluster dan 1000 data training akan terbent $u k$ matrik $\varphi(999 \times 2)$, matrik $w(2 \times 1)$ dan matrik $t(999 \times 1)$. Pada struktur RBF-NN dengan 3 cluster, matrik $\varphi$ yang terbentuk berdimensi (999 x 3), matrik $w$ berdimensi $(3 \times 1)$ dan matrik $t(999 \times 1)$. Bobot $w$ dapat dihitung melalui (2).

d. Setelah matrik $w$ ditentukan, maka hasil perkalian matrik $\varphi$ dan matrik $w$ merupakan hasil peramalan atau keluaran dari sistem, sementara matrik $t$ merupakan target yang harus dicapai. Penghitungan error (MAPE) dilakukan sesuai (5), jadi hasil perkalian $\varphi$ dan $w$ diambil sebagai nilai $A_{t}$, nilai $F_{t}$ diambil dari matrik $t$, dan $n$ sesuai jumlah data. Misalkan hasil peramalan ke1 sampai ke-5 memberikan nilai : 1,$1 ; 1,2 ; 1,3 ; 1,4$; 1,5 dan nilai dari matrik $t$ sebagai target ke-1 sampai ke-5 adalah : 1,$2 ; 1,2 ; 1,3 ; 1,2 ; 1,5$, maka nilai MAPE yang diperoleh :

$$
\begin{aligned}
M A P E=\left(\frac{100}{5}\right)\left[\left|\frac{1,2-1,1}{1,2}\right|+\left|\frac{1,2-1,2}{1,2}\right|+\left|\frac{1,3-1,3}{1,3}\right|+\right. & \\
& \left.\left|\frac{1,2-1,4}{1,2}\right|+\cdots+\left|\frac{1,5-1,5}{1,5}\right|\right] \\
= & 0,2778 .
\end{aligned}
$$

e. Proses pada cluster lainnya (selain 2 cluster) berjalan dalam tahapan yang sama. Perubahan hanya terjadi pada dimensi matrik $\varphi$ dan matrik $w$ saja.

\section{Optimasi dengan AG/AGA}

Setiap elemen dari matrik $w$ akan menjadi kromosom pada proses optimasi, diikuti dengan proses penambahan kromosom agar menjadi 100 buah menggunakan bantuan bilangan acak. Kromosom ini akan mendapat perlakuan yang berbeda-beda tergantung tipe AG dan AGA yang digunakan.

Misalnya pada AG tipe I dengan 2 cluster, matrik $w$ yang terbentuk adalah sebagai berikut:

$$
\left[\begin{array}{lllllllllll}
1 & 2 & 3 & 4 & 5 & 6 & 7 & 8 & 9 & \cdots & 100 \\
1 & 2 & 3 & 4 & 5 & 6 & 7 & 8 & 9 & \cdots & 100
\end{array}\right]
$$

Jika crossover dengan bilangan acak memenuhi ketentuan bahwa bobot 91 hingga 100 diganti dengan 1 sampai dengan 10, maka elemen di kolom 91 hingga 100 akan diganti dengan elemen pada kolom 1 hingga 10. Jika bilangan acak yang dihasilkan memberikan ketentuan bahwa elemen 91 hingga 100 diberikan tanda negatif, maka matrik $w$ yang baru terbentuk akan menjadi :

$$
\left[\begin{array}{lllllllllllll}
1 & \cdots & 1,1 & 12 & 0,3 & 1,5 & 5,3 & 4 & 1,7 & 2,1 & -2 & 3 \\
1 & \cdots & 1,1 & 12 & 0,3 & 1,5 & 5,3 & 4 & 1,7 & 2,1 & -2 & 3
\end{array}\right]
$$

Proses mutasi dilakukan dengan mengalikan bobot pada kolom 91 hingga 100 dengan bilangan acak lalu dikalikan kembali dengan 100. Jika syarat untuk mutasi terpenuhi maka matrik $w$ yang terbentuk adalah :

$$
\begin{aligned}
& {\left[\begin{array}{llllllllllll}
1 & \cdots & 0,23 & 2,2 & 3,12 & 4,87 & 1,5 & 2,6 & 0,73 & 1,432 & -1,201 & 0,5 \\
1 & \cdots & 0,18 & 2,4 & 3,14 & 4,85 & 1,57 & 2,6 & 0,72 & 1,432 & -1,201 & 0,5
\end{array}\right]}
\end{aligned}
$$

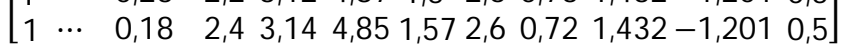

Setelah matrik $w$ diperoleh, maka proses selanjutnya adalah memasukkan kembali matrik $w$ ini ke dalam skema RBF-NN 
di atas, untuk mencari MAPE-nya. Demikian seterusnya hingga proses mencapai batas akhir yaitu 50 epoch.

Proses AGA memiliki sedikit perbedaan pada tahapan crossover dan mutasi. Jika diambil matrik $w$ pada contoh sebelumnya :

$$
\left[\begin{array}{lllllllllll}
1 & 2 & 3 & 4 & 5 & 6 & 7 & 8 & 9 & \cdots & 100 \\
1 & 2 & 3 & 4 & 5 & 6 & 7 & 8 & 9 & \cdots & 100
\end{array}\right]
$$

maka harus ditentukan dulu nilai fitness dari masing-masing kromosom, dengan cara mencari nilai MAPE-nya. Untuk mencari MAPE, caranya sama dengan pada metode AG. Nilai fitness lalu ditentukan berdasarkan perbandingan terbalik dari MAPE.

Jadi jika diasumsikan hanya ada 4 kromosom, sementara nilai MAPE yang diperoleh kromosom 1 adalah 0,1 ; kromosom 2 adalah 0,2 ; kromosom 3 adalah 0,3 ; kromosom 4 adalah 0,4 ; maka kromosom 1 memiliki proporsi 10, kromosom 2 memiliki proporsi 5, kromosom 3 sebesar 3,3 dan kromosom 4 sebesar 2,5. Nilai total proporsi menjadi 20,8. Fitness dari kromosom 1 menjadi 0,487; kromosom 2 menjadi 0,24; kromosom 3 menjadi 0,144 ; dan kromosom 4 menjadi 0,12 . Nilai fitness ini akan digunakan dalam perhitungan untuk menentukan apakah kromosom itu layak untuk menjalani proses crossover dan mutasi atau tidak. Jika misalnya ditentukan $p_{c}=0,3$, dengan $\mathrm{k} 1=0,7$ maka perhitungan probabilitas crossover untuk kromosom 2 menjadi :

$$
\begin{aligned}
p_{2} & =0,7 \times(0,487-0,24)(0,487-0,248) \\
& =0,041 .
\end{aligned}
$$

Karena nilai probabilitasnya yang tidak sama dengan atau lebih dari $p_{c}$ maka kromosom 2 tidak menjalani proses crossover. Perhitungan untuk probabilitas mutasi dilakukan dengan cara yang sama.

\section{E. Proses Pengujian}

Proses pengujian menggunakan matrik $w$ dan $\varphi$ yang dihasilkan dari proses sebelumnya dan matrik $t$ yang berisikan data pengujian. Penghitungan error (MAPE) dilakukan melalui cara yang sama dengan perhitungan RBF-NN. Hal ini terus dilakukan sampai data pengujian habis, seperti ditunjukkan pada Gambar 2.

Seperti diutarakan sebelumnya pada Pendahuluan, penulis menggunakan model RBF-NN dengan 2 neuron hingga 5 neuron (sesuai jumlah cluster). Pada setiap neuron, akan dihasilkan 1 nilai MAPE dari metode RBF-NN murni dan 6 nilai MAPE dari metode RBF-NN yang telah dioptimasi. Pembandingan dilakukan untuk seluruh nilai MAPE dan metode peramalan dengan nilai MAPE terkecil dianggap sebagai yang terbaik.

Nengah Widiangga: Analisis Metode RBF-NN dengan...



Gambar 2: Algoritma pengujian model RBF-NN

\section{HASIL DAN ANALISIS}

Berdasarkan percobaan yang telah dilakukan, rangkuman MAPE untuk data daily low diberikan pada Tabel I dan untuk data daily high diberikan pada Tabel II.

\begin{tabular}{|c|c|c|c|c|c|}
\hline CLUSTER & METODE & MINIMUM & MAKSIMUM & RATA-RATA & R.ANGE \\
\hline \multirow{7}{*}{2} & RBF & 0,2850 & 0,2850 & 0,2850 & 0,0000 \\
\hline & $\mathrm{AGI}$ & 3,8148 & 892,8504 & 247,9353 & 889,0356 \\
\hline & AG II & 0,2564 & 0,2735 & 0,2661 & 0,0171 \\
\hline & AG III & 1,6456 & 371,4353 & 80,4266 & 369,7897 \\
\hline & AGA I & 1,6089 & 22,7953 & 5,7681 & 21,1864 \\
\hline & AGA II & 0,2394 & 0,2850 & 0,2656 & 0,0456 \\
\hline & AGA III & 1,6086 & 8,1860 & 2,9226 & 6,5773 \\
\hline \multirow{7}{*}{3} & RBF & 0,2297 & 0,2297 & 0,2297 & 0,0000 \\
\hline & $\mathrm{AGI}$ & 1,6276 & 319,1932 & 157,3949 & 317,5655 \\
\hline & $\mathrm{AG} \mathrm{II}$ & 0,2286 & 0,2297 & 0,2290 & 0,0011 \\
\hline & AG III & 1,6402 & 4249,8330 & 948,1636 & 4248,1929 \\
\hline & AGA I & $2,580 \mathrm{~s}$ & 18,6688 & 8,2317 & 16,0880 \\
\hline & AGA II & 0,2287 & 0,2295 & 0,2289 & 0,0008 \\
\hline & AGA III & 1,5064 & 10,9515 & 4,7124 & 9,4451 \\
\hline \multirow{7}{*}{4} & RBF & 0,2297 & 0,2301 & 0,2299 & 0,0004 \\
\hline & $\mathrm{AGI}$ & 13,7706 & 768,4714 & 248,1263 & 754,7007 \\
\hline & AG II & 0,2287 & 0,2292 & 0,2289 & 0,0005 \\
\hline & AG III & 5,7386 & 401,1650 & 99,8861 & 395,4264 \\
\hline & AGA I & 2,9206 & $30,279 \mathrm{~g}$ & 12,7766 & 27,3592 \\
\hline & AGA II & 0,2286 & 0,2292 & 0,2289 & 0,0006 \\
\hline & AGA III & 1,7844 & 6,66661 & 3,7177 & 4,8816 \\
\hline \multirow{7}{*}{5} & RBF & 0,2296 & 0,2314 & 0,2305 & 0,0018 \\
\hline & $\mathrm{AGI}$ & 2,5824 & 388,7684 & 161,0236 & 386,1860 \\
\hline & $\mathrm{AG} \mathrm{II}$ & 0,2289 & 0,2295 & 0,2292 & 0,0005 \\
\hline & AG III & 7,7424 & 4070,4841 & 557,4044 & 4062,7417 \\
\hline & AGA I & 2,7496 & 20,3761 & 8,6517 & 17,6265 \\
\hline & AGA II & 0,2287 & 0,2289 & 0,2288 & 0,0002 \\
\hline & AGA III & 1,7087 & 10,2382 & 4,8698 & 8,5295 \\
\hline
\end{tabular}

TABEL I

RANGKUMAN MAPE DATA DAILY LOW

p-ISSN:1693 - 2951; e-ISSN: 2503-2372 
TABEL III

RANGKUMAN MAPE DATA DAILY HIGH

\begin{tabular}{|c|c|c|c|c|c|}
\hline CLUSTER & METOOE & MINIMUM & MAKSIMUM & RATA-RATA & RANGE \\
\hline \multirow{7}{*}{2} & RBF & 0,2922 & 0,2977 & 0,2950 & 0,0055 \\
\hline & $\Delta G_{I}$ & 15,5548 & 245,6913 & 156,6447 & 230,1365 \\
\hline & 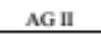 & 0,2339 & 0,2874 & 0,2766 & 0,0534 \\
\hline & AGIII & 17,7578 & 522,5397 & 126,9847 & 504,7819 \\
\hline & AGAI & 1,5494 & 28,7295 & 8,7868 & 27,1801 \\
\hline & AGA II & 0.2576 & 0,2983 & 0.2814 & 0,0407 \\
\hline & AGA III & 1,6291 & 5,3581 & $2,62 \times 2$ & 3,7290 \\
\hline \multirow{7}{*}{3} & RBF & 0.2195 & 0,2195 & 0.2195 & 0,0000 \\
\hline & $A G_{1}$ & 6,8694 & 360,1166 & 116,9075 & 353,2472 \\
\hline & AGIII & 0,2192 & 0,2200 & 0,2194 & 0,0008 \\
\hline & $\mathrm{AGIII}$ & 3,5786 & 718,5100 & 142,8501 & 714,9315 \\
\hline & AGAI & 1,6860 & 15,0499 & 7,9187 & 13,3640 \\
\hline & AGA II & 0,2190 & 0,2197 & 0,2193 & 0,0007 \\
\hline & AGA III & 1,6927 & 7,9883 & 4,1912 & 6,2956 \\
\hline \multirow{7}{*}{4} & RBF & 0,2196 & 0,2198 & 0,2197 & 0,0002 \\
\hline & $A G I$ & 92,8449 & 344,3286 & 198,9158 & 251,4837 \\
\hline & AGIII & 0,2193 & 0,2201 & 0,2198 & 0,0007 \\
\hline & MGIII & 3,7275 & 4459,4744 & 638,5886 & 4455,7470 \\
\hline & AGAI & 1,6218 & 31,7179 & 10,4850 & 30,0961 \\
\hline & AGA II & 0,2193 & 0,2199 & 0,2197 & 0,0006 \\
\hline & AGA III & 1,4371 & 11,6124 & 4,0321 & 10,1753 \\
\hline \multirow{7}{*}{5} & RBF & 0,2195 & 0,2204 & 0,2200 & 0,0009 \\
\hline & $A G I$ & 134,8533 & 739,3607 & 340,8346 & 604,5074 \\
\hline & AGIII & 0,2193 & 0,2201 & 0,2197 & 0,0008 \\
\hline & MGIII & 7.1666 & 761,6106 & 154,6047 & 754,4440 \\
\hline & AGAI & 3,0750 & 19,7273 & 8,0105 & 16,6523 \\
\hline & AGAII & 0.2194 & 0,2201 & 0.2198 & 0,0007 \\
\hline & AGA III & 1.6338 & 13,7531 & 5,1754 & 12,1193 \\
\hline
\end{tabular}

Nilai MAPE yang diperoleh pada seluruh cluster, seperti terlihat pada Tabel I dan Tabel II, menunjukkan bahwa metode AG II dan AGA II mampu memberikan optimasi terhadap hasil peramalan oleh RBF-NN.

Perbaikan pada RBF-NN tidak memberikan optimasi yang signifikan pada model dengan banyak cluster [7]. Hal tersebut sejalan dengan penelitian ini dimana pada model dengan 3 hingga 5 cluster, selisih MAPE antara RBF-NN tanpa optimasi dengan RBF-NN yang dioptimasi AG II dan AGA II tidak sebesar pada model dengan 2 cluster.

Metode selain AG II dan AGA II memberikan kurva hasil peramalan yang bentuknya mendatar, tidak variatif dan tidak mengikuti data Forex aktual seperti ditunjukkan Gambar 3.

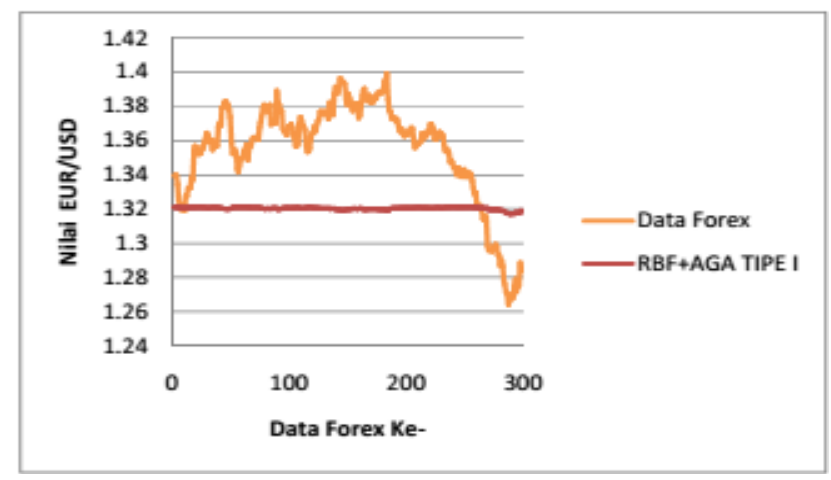

Gambar 3 : Kurva hasil peramalan RBF-NN + AGA I yang nyaris mendatar
Kurva yang mendatar ini disebabkan oleh nilai bobot yang kecil, yang berpengaruh terhadap hasil peramalan, dimana hasil peramalan nilainya ditentukan berdasarkan perkalian bobot dengan fungsi $\varphi$.

Selain itu, hasil peramalan dari metode selain AG II dan AGA II memiliki initial point yang jauh, sehingga meskipun kurva peramalan bentuknya mirip namun nilai MAPE-nya tetap besar, seperti ditunjukkan pada Gambar 4. Initial point yang jauh adalah konsekuensi dari pencarian secara acak di dalam search space (ruang pencarian) yang baru.

Kurva hasil peramalan AG II ditunjukkan pada Gambar 5, dan kurva hasil peramalan RBF-NN tanpa optimasi ditunjukkan pada Gambar 6. Seperti terlihat pada Gambar 6, kurva hasil peramalan berhimpit dengan kurva data forex aktual.

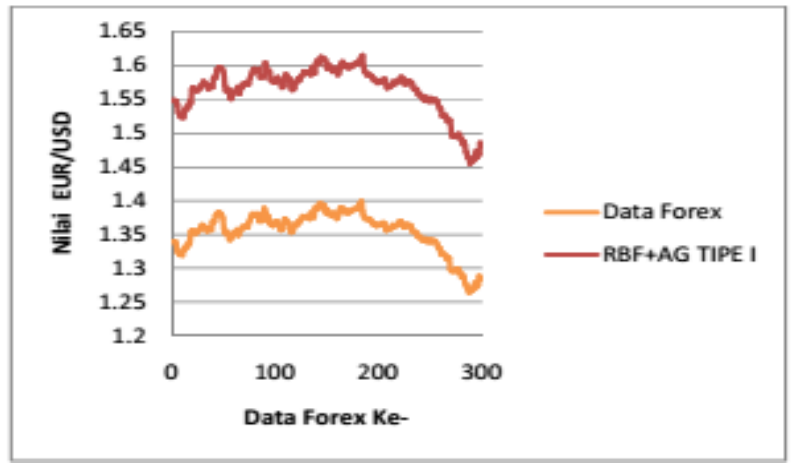

Gambar 4 : Kurva hasil peramalan RBF-NN + AG Tipe I dengan initial point terlalu jauh



Gambar 5 : Kurva hasil peramalan RBF-NN + AG II

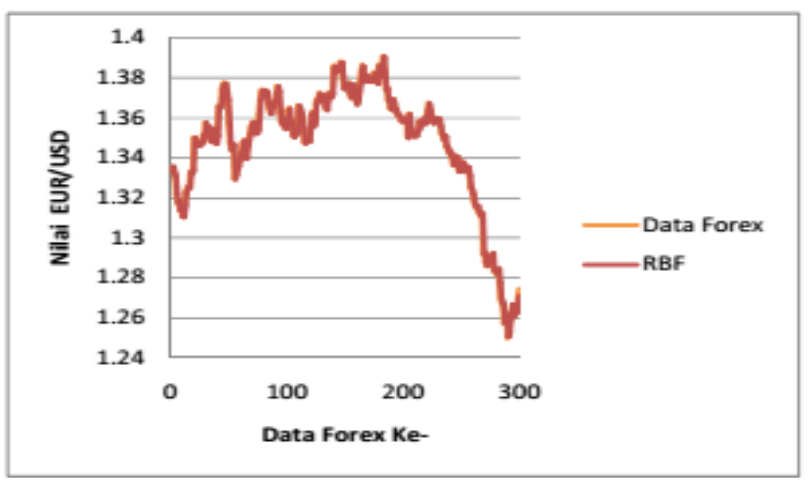

Gambar 6 : Kurva hasil peramalan RBF-NN tanpa optimasi 
Keunggulan Algoritma Genetika II dan Algoritma Genetika Adaptif II didukung oleh langkah pencarian yang dilakukan di dekat nilai bobot yang dihasilkan RBF-NN tanpa optimasi [7]. Hal ini terlihat dari range MAPE dari AG II dan AGA II yang kecil pada cluster 3, 4, 5 dan menyerupai range MAPE milik RBF-NN tanpa optimasi.

Langkah pencarian di dekat bobot RBF-NN ini terbukti lebih efektif dalam kasus mata uang EUR/USD daripada melakukan pencarian di search space (ruang pencarian) yang baru, seperti yang dilakukan metode AG/AGA selain AG II dan AGA II.

\section{KESIMPULAN DAN SARAN}

Kesimpulan yang diperoleh dari penelitian ini adalah sebagai berikut.

1. Pada data daily low, metode terbaik adalah Algoritma Genetika II (3 cluster) dengan MAPE sebesar 0,2286\%, sementara pada data daily high metode terbaik adalah Algoritma Genetika Adaptif II (3 cluster) dengan MAPE sebesar 0,2190\%. Metode AG II dan AGA II mampu memberikan optimasi yang ditunjukkan dengan nilai MAPE-nya yang lebih kecil daripada metode RBF-NN tanpa optimasi. Nilai MAPE terbaik yang diha-silkan AG/AGA cenderung fluktuatif karena metode ini didasarkan pada mekanisme probabilitas.

2. Metode AG II dan AGA II memberikan kurva hasil peramalan yang mendekati data Forex aktual karena didukung teknik pencarian di dekat bobot RBF-NN. Metode AG/AGA yang lain memberikan MAPE yang besar karena kurva hasil peramalan yang bentuknya cenderung mendatar, tidak variatif dan initial point jauh dari data Forex aktual.

Satu kali simulasi RBF-NN dengan optimasi AG/AGA dalam MATLAB dapat memakan waktu hingga 15 menit. Penelitian selanjutnya dapat mencoba cara/teknik lain sehingga waktu simulasi bisa dipersingkat.

\section{REFERENSI}

[1] Huda, F. A., Ridok. A., Dewi. C., 2013, Peramalan Time Series Saham Menggunakan Backpropagation Neural Network Berbasis Algoritma Genetika, Teknik Informatika PTIIIK, Universitas Brawijaya.

[2] Bank for International Settlements, 2014. Triennial Central Bank Survey. Monetary and Economic Department.

[3] Georgios Sermpinis, Konstantinos Theofilatos, Andreas Karathanasopoulos, Efstratios F. Georgopoulos, Christian Dunis, 2012. Forecasting Foreign Exchange Rates with Adaptive Neural Networks Using Radial-Basis Functions and Particle Swarm Optimization. European Journal Operation Research 225, 528-540. doi:http://dx.doi.org/10.1016/j.ejor.2012.10.020.

[4] Zuliana, S.U., 2012. Penerapan Global Ridge-Regression Pada Peramalan Data Time Series Non Linear Studi Kasus : Pemodelan Nilai Tukar US Dollar Terhadap Rupiah. Kaunia VIII.

[5] Warda, S. M., Irhamni F., 2012. Analisa Data Antaran Pos Express Menggunakan Metode Radial Basis Function Neural Network (RBFNN) Study PT. POS Indonesia (Persero) Surabaya. Universitas Trunojoyo.

[6] Maillard, E.P., Gueriot, D., 1997. RBF neural network, basis functions and genetic algorithm, in: International Conference on Neural Networks,1997. Presented at the International Conference on Neural Networks,1997, pp. 2187-2192 vol.4. doi:10.1109/ICNN.1997.614247.

Nengah Widiangga: Analisis Metode RBF-NN dengan...
[7] Wiharto, Y.S. Palgunadi, Muh Aziz Nugroho, 2013. Analisis Penggunaan Algoritma Genetika Untuk Perbaikan Jaringan Syaraf Tiruan Radial Basis Function. Seminar Nasional Teknologi Informasi Dan Komunikasi 2013. SENTIKA 2013.

[8] Heriyanto, D. N., Rachman, F.H., Satoto, B.D., 2013. Penerapan Metode Radial Basis Function Network dengan K-Means Cluster untuk Peramalan Kebutuhan Straw. Jurnal Sarjana Teknik Informatika. Universitas Trunojoyo Madura 1, 1-10.

[9] Andreasson, N., Evgrafov, A., Patriksson, M., 2006. Introduction to Continuous Optimization: Foundations and Fundamental Algorithms, 1st edition. Studentlitteratur AB.

[10] Dharma, A., Robandi, I., Purnomo, M.H., 2011. Application of Interval Type-2 Fuzzy Logic System in Short Term Load Forecasting on Special Days. IPTEK Journal for Technology and Science 22. doi:10.12962/ j20882033.v22i2.65. 
[Halaman Ini sengaja di kosongkan] 